\title{
Simpler and More Accurate: Weighing the Mercury in Electrolytic Cells by Radiotracer Dilution Method
}

\author{
Sugiharto $^{1^{*}}$, S.B. Santoso ${ }^{1}$ and G.B. Santoso ${ }^{2}$ \\ ${ }^{I}$ Center for Application of Isotopes and Radiation Technology, National Nuclear Energy Agency \\ Jl. Lebak Bulus Raya No. 49, Jakarta 12440, Indonesia \\ ${ }^{2} P T$. Industri Soda Indonesia \\ Jl. Raya Waru 31, Sidoarjo 61256, Indonesia
}

\section{ARTICLE INFO}

\section{Article history:}

Received 20 November 2009

Received in revised form 31 August 2010

Accepted 31 August 2010

Keywords:

Radiotracer dilution method

Electrolytic cells

Radioisotope mercury ${ }^{203} \mathrm{Hg}$

Mercury inventory

\begin{abstract}
A B S T R A C T
Weight of mercury in electrolytic cell of soda industry is usually measured gravimetrically, which is typical labor work in character. Error sources of the gravimetric method might have come from the fact that some mercury's are usually trapped in the cell due to complicated structure of electrolytic cell. This cause unknown errors. In addition, formation of amalgam at the cathode may cause a further uncertainty in the measurement. Total error from gravimetric method is $4 \%$ on average. Radiotracer dilution method provides advantages either for simplification of procedure and reduction of measurement error. In this experiment radioisotope mercury ${ }^{203} \mathrm{Hg}$, which was prepared in nuclear reactor was used to examine 13 of 14 electrolytic cells of soda plant. Each electrolytic cell was designed containing approximately $700 \mathrm{~kg}$ inactive mercury. Before injection, the radioisotope mercury was mixed with non radioisotope mercury in a bath to obtain a suitable injection aliquots and standard references. Calibration curve, which was derived from two stage dilution processes taken from standard references, was used to examine degree of mixing between radioisotope and non radioisotope mercury and it was also used in weight calculation of non radioisotope mercury in electrolytic cell. Injection was carried out simply by pouring the injection aliquots into the flowing mercury at the inlet side of the cell. Mercury samples from the cells were extracted at regular time intervals and filled into vials for counting. This was done for the primary conformation of the completeness of mixing of the tracer with the non radioisotope mercury in each cell. When complete mixing is achieved, the unknown quantity of mercury in each cell was calculated based on mass balance principle. From the calculation the weight of mercury in each electrolytic cell was not the same and maximum error of measurement obtained from this method is $2.48 \%$. Compared to gravimetrically error mentioned above, it was clear that radiotracer dilution method gives better result in terms of higher accuracy and simpler procedure in measurement of the weight of mercury in electrolytic cells. Above all, this method is very suitable to be implemented in soda industry.
\end{abstract}

(C) 2010 Atom Indonesia. All rights reserved

\section{INTRODUCTION}

A radiotracer dilution method was implemented to study mercury inventory in electrolytic cells of the caustic soda plant at Waru Chemical Industry, Sidoarjo, East Java. The plant was 40 years old, produces approximately 30 tons/day of caustic soda, 17 tons/day of chlorine and 10 tons/day of hydrochloric acid. Caustic soda is produced by means of electrolysis of the brine. The plant has 27 electrolytic cells comprising of 14 cells each with approximately $700 \mathrm{~kg}$ of mercury

\footnotetext{
* Corresponding author.

E-mail address: sugi@batan.go.id (Sugiharto)
}

and 13 cells each with approximately $1700 \mathrm{~kg}$ of mercury [1].

Inventory of mercury in electrolytic cells must be regularly examined, since the mercury is not only expensive but it is also a potential pollutant to environment. Presence of mercury in the cell and the consumption of mercury per ton to produce chlorine are both important from economic view point. Visual inspection around the plant shows that loss of mercury appears to occur through sludge, waste water and drainage. Pilferage is not ruled out and amalgam levels are unknown. Replenishment of mercury is carried out by plant personnel when the water in the cell is not clear. 
Conventional method of mercury inventory is usually carried out gravimetrically. The disadvantages of the method are as follows: (a) the plant operation must be stopped for draining out of the mercury from electrolytic cell. This action yield in loss of production, (b) all mercury is not often possible to drain out as some of it is usually trapped in the cell. This cause unknown errors and (c) sodium liberated at the cathode forms amalgam with mercury causing a further uncertainty in the measurement $[3,4]$.

The radiotracer dilution method for mercury inventory using radioisotope mercury ${ }^{197} \mathrm{Hg}$ was demonstrated by Enomoto et al [3] whereas the use of radioisotope mercury ${ }^{203} \mathrm{Hg}$, for the same purpose has been reported by UNDP/IAEA [4], IAEA [5] and recently by Sugiharto et al [6]. The advantages of the radiotracer dilution method over gravimetric one are that (a) the operation of the plant is not necessary be stopped, (b) the remnant of radioactivity in the cell is negligible, (c) inaccuracy measurement due to amalgam formation can be avoided because the amalgam can be breaking down in the sample taken for measurement. (d) procedure of implementation is relatively simple and higher accuracy of measurement is achieved [3-5]. The radiological safety aspects of the experiment were considered safe during the planning of the study by adopting the safety standards of the International Atomic Energy Agency [7].

The purpose of this experiment is to demonstrate the applicability of radiotracer dilution method for routine inventory of mercury in the electrolytic cells. Thirteen of 14 electrolytic cells each contain approximately $700 \mathrm{~kg}$ inactive or non radioisotope mercury were examined by injection of ${ }^{203} \mathrm{Hg}$ radiotracer. Cell number 13 is dead and not reported here. This paper reported the simple procedure for weighing the mercury in electrolytic cells. Weigh of mercury is calculated based on a simple mass balance principle of the radiotracer dilution method.

\section{THEORY}

Caustic soda is produced according to the following reaction $[1,2]$ :

$$
\begin{array}{ll}
\text { Anode } \quad: 2 \mathrm{Cl}^{-} & \longrightarrow \mathrm{Cl}_{2}+2 \mathrm{e}^{-}(1) \\
\text { Chatode }: \stackrel{2 \mathrm{Hg}+2 \mathrm{Na}^{+}+2 \mathrm{e}^{-} \longrightarrow 2 \mathrm{NaHg}}{\longrightarrow}(2) \\
2 \mathrm{NaCl}+2 \mathrm{Hg} \longrightarrow 2 \mathrm{NaHg}+\mathrm{Cl}_{2}(3)
\end{array}
$$

Mercury is used as the cathode, flowing as a thin liquid sheet over the bed, carbon as the anode and molten sodium chloride forms the electrolyte. Sodium that forms amalgam at the cathode is removed by reacting it with fresh water in the decomposer, according to following reaction.

$$
\mathrm{NaHg}+\mathrm{H}_{2} \mathrm{O} \longrightarrow \mathrm{NaOH}+\mathrm{Hg}+\frac{1}{2} \mathrm{H}_{2}
$$

The clean mercury is then pumped back to the cell.

The weight of mercury in an electrolytic cell is calculated based on mass balance principle of radiotracer dilution method. Suppose radioisotope mercury with mass $m(\mathrm{~g})$ and activity or radiation intensity $C_{i}$ (cps - an abbreviation for count per second) is injected into electrolytic cell containing non radioisotope mercury of mass $M(\mathrm{~g})$. After injection and uniform mixing is achieved, the radiation intensity of mercury in electrolytic cell becomes $C_{s}$ (cps). In such situation, the following relation applies [3-5]

$$
m C_{i}=(m+M) C_{s}
$$

As $m \ll \mathbf{M}$, therefore the equation above can be written as,

$$
M=m \frac{C_{i}}{C_{s}}
$$

In practice, the radiation intensity of the radioisotope mercury, $C_{i}$, is measured indirectly because its radioactivity is very high. To optimize the procedure, after taking from nuclear reactor, the radioisotope mercury is diluted with non radioisotope mercury in a bath for lowering the count-rate of diluted radioisotope mercury. By implementation this strategy, the activity of radioisotope mercury, $C_{i}$, can be represented as product of dilution factor, $D$ (dimensionless) with corresponding to its activity, $S$ (cps). Consequently, the equation (2) can be represented in the form

$$
M=\frac{m D S}{C_{s}}
$$

\section{EXPERIMENTAL METHODS}

There are two suitable radionuclide of mercury that are available for mercury inventory: ${ }^{197} \mathrm{Hg}$ and ${ }^{203} \mathrm{Hg}$. The properties of these radionuclide are presented in Table 1 [3-5,8]. In this experiment, radionuclide mercury ${ }^{203} \mathrm{Hg}$ has been selected as radiotracer because of its longer half life, suitable energy and easy for long distance transport. 
Table 1. Characteristic of ${ }^{197} \mathrm{Hg}$ and ${ }^{203} \mathrm{Hg}$

\begin{tabular}{|c|c|c|}
\hline \multirow[t]{2}{*}{ Characteristics } & \multicolumn{2}{|c|}{ Radionuclide } \\
\hline & ${ }^{197} \mathrm{Hg}$ & ${ }^{203} \mathrm{Hg}$ \\
\hline Half-life (days) & 2.67 & 46.59 \\
\hline Gamma Energy (keV) & $77(19 \%)$ & $280(86 \%)$ \\
\hline $\begin{array}{l}\text { Long distance } \\
\text { transport }\end{array}$ & Difficult & Easy \\
\hline
\end{tabular}

Radionuclide ${ }^{203} \mathrm{Hg}$ is produced by irradiating mercury oxide in a nuclear reactor for three weeks. After taking out from nuclear reactor, the radioisotope mercury was then cooled for one day. The radioisotope mercury is then dissolved in nitric acid and converted into metallic form by an isotopic-exchange reaction. Moisture that is exerted from this reaction is removed afterward. Due to its high radioactivity, the radioisotope mercury is mixed with non radioisotope mercury and agitated in a bath to ensure that the mercury was mixed thoroughly. Mercury from the bath is then distributed into 18 screws capped - polypropylene glass vials, 13 of which are prepared as injection aliquots and the rest are prepared as standard references. Each vial contains approximately $50 \mathrm{~g}$ radioisotope mercury. Each aliquot vial is numbered correspond to the cell number into which the radiotracer is injected.

Background measurement was carried out by taking out non radioisotope mercury sample from each cell. The sample is then treated with 15-20\% $\mathrm{HCl}$ to break the amalgam and then filled into standard vials for counting. The samples are marked with the number of cell from which each sample is taken.

Injection of radioactive mercury is performed simply by pouring the injection aliquot into the flowing mercury at the inlet side of the cell. Since the tracer in the all vials is from the same lot, the specific activity should be the same. After injection, mercury in each electrolytic cell are sampled at regular interval time and filled into the standard vials for counting. The regular sampling is done for the primary conformation of the completeness of mixing of the radioisotope mercury with the non radioisotope mercury in each cell. The justification of completeness of mixing is adopted by comparing the standard deviation of the count rates of a group of successive samples. When standard deviation become comparable, the completeness of the mixing was considered adequate. In this experiment the adequate mixing for all cells was achieved two days after injection. At the end of the mixing period, all the cell samples, background samples and reference standards are all counted in the well type scintillation counter. The simple procedure of experiment is summarized in Fig.1.

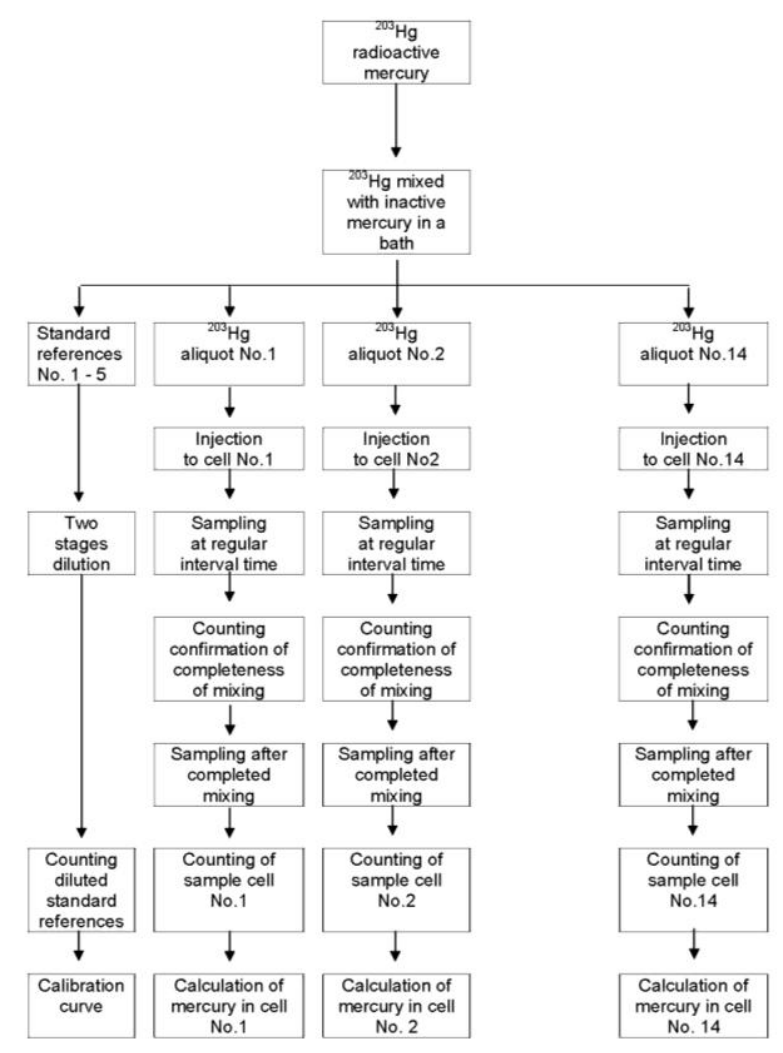

Fig. 1. Block diagram showing a simple procedure implemented in this experiment

In this experiment, calibration curve was constructed to examine the consistency of level mixing between radioisotope mercury and non radioisotope mercury, as depicted in the first column of Fig.1. Due to high radioactivity of standard references taken from a bath, the mixing level was performed by strategy of two stages dilution procedure. This procedure was to minimize the use of radioisotope mercury and non radioisotope mercury. Detailed two stages dilution procedure was demonstrated as follow:

\section{First stage of dilution}

Weight of injection aliquot $\left(w_{1}\right)$

(taken from standard reference)

Weight of non radioisotope mercury $\left(W_{1}\right): 402.86 \mathrm{~g}$ First stage dilution factor

$D_{1}=\left(w_{1}+W_{1}\right) / w_{1}$

\section{Second stage of dilution}

Weight of aliquot from first stage of

dilution $\left(w_{2}\right) \quad: 2.06 \mathrm{~g}$

Weight of non radioisotope mercury $\left(W_{2}\right): 132.72 \mathrm{~g}$ 
Second stage dilution factor

$D_{2}=\left(w_{2}+W_{2}\right) / w_{2}$

Total dilution factor $D=\left(D_{1} x D_{2}\right)=13177.55$

\section{RESULTS AND DISCUSSION}

Five vials containing diluted standard references of mixed mercury were measured for constructing the calibration curve, as summarized in Fig.2. As can be seen in Fig. 2 that mixing uniformity of mercury in each vial were considerable good as indicated by the value of correlation factor $\left(\mathrm{R}^{2}\right)$ which very close to one. In this experiment calibration curve was used to examine the consistency of the mixing level for each dilution stage and it was also used for calculation of weight of mercury.

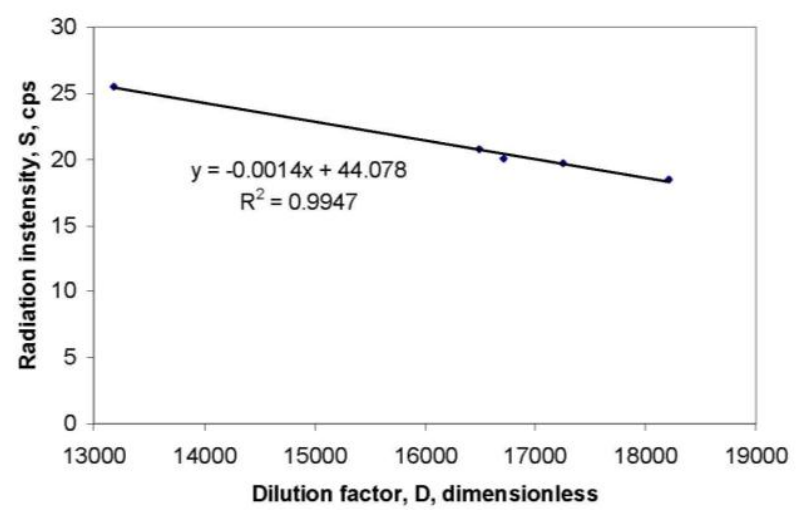

Fig. 2. Calibration curve derived from two stages dilution process of standard references

Estimated error of measurement might have resulted from counting statistic and weighing procedures [3-5]. Full equation of the error is

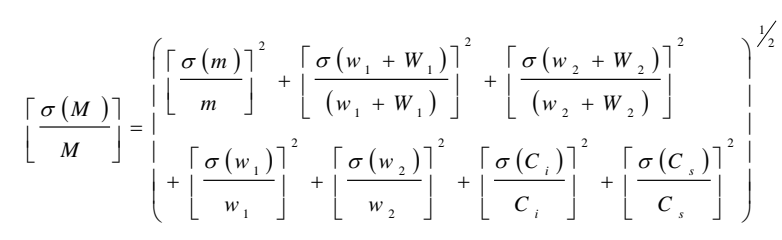

It may be noted that in this experiment error due to inadequacy of mixing of radioisotope mercury with non radioisotope mercury in electrolytic cell is greater importance compared with the error due to weighing procedure. Based on this fact, the equation above can be reduced to

$$
\left\lceil\frac{\sigma(M)}{M}\right\rfloor=\left(\left\lceil\left\lfloor\frac{\sigma\left(C_{i}\right)}{C_{i}}\right]^{2}+\left\lceil\frac{\sigma\left(C_{s}\right)}{C_{s}}\right]^{2}\right)^{\frac{1}{2}}\right.
$$

$$
\left\lceil\frac{\sigma(M)}{M}\right\rfloor=\left(\frac{1}{C_{i}^{2}}\left\lceil\frac{\left(C_{i}+B\right)}{T_{S}}+\frac{B}{T_{B}}\right\rceil+\frac{1}{C_{s}^{2}}\left\lfloor\frac{\left(C_{s}+B\right)}{T_{C}}+\frac{B}{T_{B}}\right\rceil\right)^{\frac{1}{2}}
$$

where $T_{S}$ is counting time with standard references (s), $T s$ is cell sample counting time (s), $B$ is background sample count rate (cps) and $T_{B}$ is background counting time (s).

Weight of mercury calculated by equation (7) come with its error calculated by equation (10) is presented in Table 2. As can be seen from the Table 2 that the amount of mercury in each cell was not the same, some of them were less and the others were more than weight design. The most important from this experiment was that the maximum error of measurement was $2.48 \%$, much lower compared to conventional one. Enomoto et al [3] reported that the error of mercury inventory by using gravimetric method was around $4 \%$ on average. It was clear that the radiotracer dilution method showed more accurate result for mercury inventory calculation

Table 2. Weight of mercury in electrolytic cell calculated by tracer dilution method and corresponding measurement errors. Each cell was designed contain approximately $700 \mathrm{~kg}$ non radioisotope mercury

\begin{tabular}{ccccc}
\hline Cell No & $m(\mathrm{~g})$ & $C_{s}$ & $M(\mathrm{~g})$ & Error $(\%)$ \\
\hline 1 & 49.63 & 24.85 & 674538 & 2.10 \\
2 & 48.89 & 18.41 & 897093 & 2.48 \\
Dead cell & - & - & - & - \\
4 & 48.84 & 14.96 & 660873 & 2.11 \\
5 & 49.41 & 22.23 & 750753 & 2.22 \\
6 & 49.91 & 27.36 & 616067 & 1.98 \\
7 & 50.25 & 31.67 & 535783 & 1.84 \\
8 & 49.68 & 25.79 & 650589 & 2.05 \\
9 & 49.99 & 21.39 & 789415 & 2.27 \\
10 & 49.77 & 28.17 & 596659 & 1.96 \\
11 & 49.02 & 25.35 & 653096 & 2.07 \\
12 & 49.62 & 28.61 & 585705 & 1.94 \\
13 & 49.88 & 25.43 & 662462 & 2.10 \\
14 & 49.55 & 22.54 & 742519 & 2.21 \\
\hline
\end{tabular}

At the end of the experiment, the personnel and the experimental area were checked for any possible radioactive contamination. The radiological safety in the fieldwork was very much improved by implementation of proper procedure in handling process of preparing the standard references. Total cumulative dose of gamma ray received by the worker is far less than acceptable maximum dose for radiation worker. This means the work was performed safely. 


\section{CONCLUSIONS}

The experiment using ${ }^{203} \mathrm{Hg}$ isotope of a 46.59 days half life has been safely implemented in soda industry. The weight of mercury calculated by mass balance of radiotracer dilution method showed that weight of mercury in each cell was not significantly same. Maximum error (standard deviation) of measurement generated from the calculation was $2.48 \%$. This figure indicates that the radiotracer dilution method provides more accurate result in determining weight of mercury compared to one of gravimetric method which account of error of $4 \%$ on average. Moreover, a relatively simple in handling and weighing procedure of the experiment are prominent advantages of this method. From this fact the radiotracer dilution method is suitable implemented to the soda industry.

\section{ACKNOWLEDGEMENT}

The authors thank to director and management staff of PT. Soda Industri Inonesia, Waru-Sidoarjo for a valuable discussion and cooperation during implementation of the project.

\section{REFERENCES}

1. G.B. Santoso, Personal Communication.

2. H.E. Le May, K.M. Ribble, H. Beall and D.C. Brower, Chemistry-Connection to Our Changing World, Upper Saddle River, Prentice-Hall (2000) 705.

3. Enomoto, et al, Int. J. of App. Rad. Isotopes $\mathbf{2 6}$ (1975) 671.

4. Anonymous, Mercury Inventory in Electrolytic Cells by a Radioactive Tracer Technique, Report RAS/86/073, UNDP/IAEA, Vienna (1988).
5. Anonymous, Guidebook on Radiotracers in Industry, Tech. Rep. Series 316, IAEA, Vienna (1990).

6. Sugiharto, Wibisono and A. Indrajaya, Paper Presented at International Conference on Advanced Nuclear and Engineering, Bandung, Indonesia, November 3-4 (2009).

7. Anonymous, Radiotracer Application in Industry, a Guidebook, Safety Rep. Series, $\mathbf{4 2 3}$ IAEA, Vienna (2004).

8. Anonymous, Radiotracer and Labeling Compounds for Applications in Industry and Environment, Report of a Consultants Meeting, IAEA, Warsaw, Poland ( 2004). 

Sugiharto, et al / Atom Indonesia Vol. 36 No. 2 (2010) 